\title{
Functional diversity and functional traits of periphytic algae during a short-term successional process in a Neotropical floodplain lake
}

\author{
Dunck, B. ${ }^{a, b *}$, Rodrigues, L. ${ }^{a, b}$ and Bicudo, DC. ${ }^{c}$ \\ ${ }^{a}$ Núcleo de Pesquisas em Limnologia, Ictiologia e Aquicultura - NUPELIA, Laboratório de Algas Perifíticas, \\ Departamento de Biologia - DBI, Universidade Estadual de Maringá - UEM, Avenida Colombo, \\ 5790, Sala 08, Bloco G-90, CEP 87020-900, Maringá, PR, Brazil

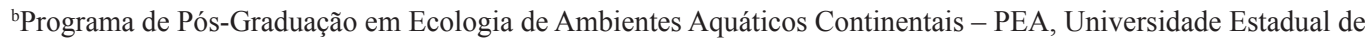 \\ Maringá - UEM, Avenida Colombo, 5790, Sala 08, Bloco G-90, CEP 87020-900, Maringá, PR, Brazil \\ 'Seção de Ecologia, Instituto de Botânica de São Paulo - IBTSP, Avenida Miguel Estéfano, \\ 3687, Água Funda, CEP 04301-902, São Paulo, SP, Brazil \\ *e-mail: dunck.barbara@gmail.com
}

Received: October 10, 2013 - Accepted: April 16, 2014 - Distributed: August 31, 2015

(With 6 figures)

\begin{abstract}
Due to the lack of knowledge in periphytic algae functional diversity patterns during successional processes in floodplains, the present study aimed to analyze the dynamics of the functional traits and functional diversity of periphytic species during a short-term successional process in a floodplain lake. The functional traits analyzed were size class, growth form, strength of attachment to the substratum, and functional strategies. We evaluated the dynamics of these traits, considering richness, density and biovolume during an 18-day colonization in two hydrological periods. The functional diversity was assessed using the mean pairwise distance index (MPD). Dominant functional traits during the colonization changed in association with the flood pulse. Under the pulse effect, higher development of C-S strategist, loosely attached, filamentous and nanoperiphytic species occurred. The highest values of functional diversity were associated with the algal biomass peak during the colonization and the high water hydrological period, possibly indicating greater efficiency in the ecosystem functioning. These findings show the importance of the functional traits approach in periphyton studies and that the selection of functional traits must be performed taking into account traits that represent the species niche.
\end{abstract}

Keywords: experiment, functional strategies, MPD, periphyton.

\section{Diversidade funcional e características funcionais de algas perifíticas em um curto processo successional em um lago de planície de inundação Neotropical}

\begin{abstract}
Resumo
Devido à ausência de conhecimento sobre os padrões para a diversidade funcional de algas perifíticas durante processo sucessional de curto tempo, o presente estudo objetivou avaliar a dinâmica das características funcionais e da diversidade funcional dessas espécies durante a sucessão em um lago de planície de inundação. As características funcionais analisadas foram classe de tamanho, forma de vida, intensidade de aderência ao substrato e estratégias funcionais. Foi avaliada a dinâmica destas características funcionais, considerando riqueza, densidade e biovolume, durante 18 dias de colonização, em dois períodos hidrológicos distintos. A diversidade funcional estimada pelo índice de distância média entre pares (MPD). As características funcionais dominantes se alteraram durante a colonização proporcionado pelo pulso de inundação. Sobre este efeito houve grande desenvolvimento de espécies C-S estrategistas, frouxamente aderidas, filamentosas e nanoperifíticas. Os maiores valores de diversidade funcional foram relacionados com o pico de biomassa algal ao longo da colonização e com o período de águas altas, e que isso provavelmente indica maior eficiência no funcionamento do ecossistema. Este estudo mostrou a importância de incluir as características funcionais nos estudos de algas perifíticas, e que a seleção de características deve ser feita levando em consideração o nicho das espécies.
\end{abstract}

Palavras-chave: experimento, estratégias funcionais, MPD, perifíton. 


\section{Introduction}

Stable and static environmental conditions are rarely found in nature; thus, ecosystems are continuously subjected to climatic changes or multiple impacts from human activities and environmental fluctuations (Weithoff, 2003). These impacts can change the intensity and competitive relationships between organisms for available resources (McCormick, 1996). Changes in aquatic ecosystems due to disturbances work as environmental filters that alter the relationships between species and the environment (Smith and Wilson, 2002) and are key factors in understanding patterns of community distribution and establishment.

In floodplains, the areas are flooded by the lateral overflow of rivers and lakes and depend on the periodic fluctuation in the water levels of these environments (Goldsborough and Robinson, 1996). In these habitats, the flood pulse represents the primary driving force responsible for the existence, productivity and interactions in the biota (Junk et al., 1989). The flood pulse concept involves the lateral exchange of water, nutrients and organisms between the main channels of rivers (or lakes) and the connected area of the floodplain (Junk and Wantzen, 2004). In this way, the flood pulse controls physical, chemical and biological processes; therefore, the analysis of the hydrological regime of rivers associated with these ecosystems has an essential role in the interpretation of ecological processes (Rodrigues and Bicudo, 2004).

In aquatic environments, periphytic algae are important for carbon sequestration, primary productivity, nutrient cycling, and food web interactions (Stevenson, 1996). Their establishment in these environments is the outcome of complex interactions between many factors, such as disturbances (Biggs et al., 1998), nutrient availability (Ferragut and Bicudo, 2009; Dunck et al., 2013a), light (Tuji, 2000) and hydrodynamics (Algarte et al., 2009).

During short-term successional processes of periphytic algae, the time taken to reach peak biomass varies, from two weeks (Stevenson, 1990) when floods are low to moderate up to several weeks under severe floods (Biggs, 1996). The establishment and development of certain species in the periphytic matrix may be favored by particular functional traits, such as morphology and cell size (Biggs, 1996; Biggs et al., 1998; Ferragut and Bicudo, 2010; Dunck et al., 2013b). In general, smaller and fast colonizing species with high dispersal capacity characterize early successional stages, and towards the climax or biomass peak of communities, species that better compete for resources and adapt to disturbances predominate (McCormick, 1996; Biggs, 1996; Biggs et al., 1998).

To date, little is known regarding the functional traits of periphytic algae and how their dynamics are linked to different environmental disturbances. Two studies started to investigate these factors. McCormick (1996) proposed a theoretical model that relates the competitive abilities of organisms, tolerance to environmental stress, and resistance to disturbance. Biggs et al. (1998) also related the functional strategies of species with the disturbance frequency and availability of resources in rivers and streams in a theoretical model. In recent studies, Ferragut \& Bicudo (2010) evaluated periphytic algae adaptive strategies under nitrogen and phosphorus artificial enrichment in a tropical oligotrophic shallow reservoir. Larson \& Passy (2012) analyzed the taxonomic and functional composition of the algal benthos during successional processes in response to nutrient supply and current velocity. Schneck \& Melo (2012) experimentally evaluated the effect of substratum roughness on the resistance and resilience of five life forms of stream benthic algae following a hydrological disturbance. Dunck et al. (2013b) analyzed the adaptive strategies and functional diversity of these communities in a floodplain lake considering the disturbance of flood pulse. Dunck et al. (2015) explored patterns in species and functional dissimilarities of periphytic algae in floodplain lakes.

One way to evaluate species functional traits is through functional diversity, which is an estimate of the differences between organisms directly from functional traits (Diaz and Cabido, 2001). These can be morphological, physiological or phonological traits that indirectly affect the efficiency of the species development, such as growth, reproduction and survival (Weithoff, 2003; De Bello et al., 2013). The species functional traits are determinant for the functioning of communities and consequently for the ecosystems (Tilman, 2001). Therefore, functional diversity is usually directly related to the ecological communities processes and the maintenance of the ecosystems functioning (Petchey and Gaston, 2006; Sobral and Cianciaruso, 2012; Lavorel et al., 2013).

Thus, due to the absence of studies on periphytic algae functional diversity during successional processes in floodplains, the present study aimed to understand how the dynamics of the functional traits and functional diversity of periphytic algae in a floodplain lake work during a short-term successional process.

We studied an 18-day colonization period (short-term successional process) in a floodplain lake under different hydrological periods (low and high water) to answer three questions: i) what functional traits (size class, growth form, strength of attachment to the substratum, and functional strategies) of periphytic algae prevailed in terms of richness, density and biovolume; ii) which attribute of the community (richness, density or biovolume) showed the most obvious difference in functional traits between hydrological periods; and iii) how periphytic algae functional diversity dynamics work along a short-term successional process in two different hydrological periods.

In the present study, we used a database from an experiment conducted on the short-term successional process of periphytic algae in artificial substratum in a floodplain lake of the Upper Paraná River floodplain. First, we evaluated the dynamics of four functional traits of these communities ( size class, growth form, strength of attachment to the substratum, and functional strategies), considering the richness, density and biovolume, during 18 days of colonization in two hydrological periods. 
Then, we evaluated the trait structure in both hydrological periods. Finally, we assessed the functional diversity from a functional traits matrix constructed with the functional traits of species in both hydrological periods.

\section{Material and Methods}

\subsection{Study area}

The studied floodplain lake is located in the Upper Paraná River, in the Paraná State, municipality of Porto Rico, Brazil. This system is a semi-lotic environment approximately $1.2 \mathrm{~km}$ long and $50 \mathrm{~m}$ wide (Pau Veio - 22 ${ }^{\circ} 44^{\prime} 50.76^{\prime \prime}$; $\left.53^{\circ} 15^{\prime} 11.16^{\prime \prime} \mathrm{W}\right)$, has a high connectivity with the Paraná River and is located at the Mutum Island. The vegetation ranges from aquatic to terrestrial systems and is composed of aquatic macrophytes, mainly Eichhornia azurea Kunth, and herbaceous and shrubby riparian vegetation (Rodrigues and Bicudo, 2001b). Furthermore, information on the study area map, limnological and climatic variables are available in Rodrigues and Bicudo (2001b).

The water levels of Paraná River ranged from 3.1 to $4.7 \mathrm{~m}$ in the high water period and from 2.2 to $3.1 \mathrm{~m}$ in the low water period (Rodrigues and Bicudo, 2001b). This environment presented changes in limnological characteristics associated with the fluctuation of the Paraná River level. In the low water period, the values of nutrients, phosphorus and nitrogen were higher (Rodrigues and Bicudo, 2001b).

\subsection{Sampling design}

Horizontally positioned wooden supports were submerged in the subsurface approximately $50 \mathrm{~cm}$ deep and placed in the littoral zones next to stands of Eichhornia azurea in the Pau Veio Lake. This aquatic macrophyte was the predominant species during both hydrological periods (Rodrigues and Bicudo, 2001a).

The wooden support had eight drawers positioned side-by-side approximately $10 \mathrm{~cm}$ apart, with each having 10 glass slides vertically positioned. A schematic figure of the wooden supports with the drawers is available in Murakami and Rodrigues (2009). These glass slides $(7.5 \times 2.5 \mathrm{~cm})$ were used as artificial substratum for periphytic algae colonization.

The colonization of periphytic algae was monitored for 18 days, immediately after insertion of the substrates, and evaluated every two days in two hydrological periods - high water (March $14^{\text {th }}$ to April $1^{\text {st }}, 1994$ ) and low water (July $7^{\text {th }}$ to August $\left.5^{\text {th }}, 1994\right)$. The glass slides were randomly collected with two replicates every sampling day. The total number of glass slides analyzed in each hydrological period was 36 , for 72 slides in total.

Periphytic material was removed from the substratum, fixed and preserved with $0.5 \%$ acetic Lugol. Samples were deposited in the herbarium of the State University of Maringá (HUM). Periphytic algae were quantified using an inverted microscope at 400x magnification, according to Utermöhl (1958). The species density was estimated according to Ros (1979), and the results were expressed in number of individuals per unit area (ind $\mathrm{cm}^{-2}$ ). The biovolume was estimated according to Hillebrand et al. (1999) by multiplying the densities by the mean biovolume of each species, and the final result was expressed in $\mathrm{mm}^{3} \mathrm{~cm}^{-2}$. We considered species richness from the quantitative analyses. Periphytic algae composition and diversity can be found in Rodrigues and Bicudo (2001a) related to the artificial substratum present in the semi-lotic system (Pau Veio Lake).

\subsection{Species traits}

A total of 112 and 93 species were found during the high and low water periods, respectively (Rodrigues and Bicudo, 2001a). These species were analyzed according to four categorical functional traits: size class (based on the phytoplankton classification of Reynolds 1997), growth form (unicellular, filamentous, or colonial), strength of attachment to the substratum (firmly or loosely attached) and functional strategies proposed by Biggs et al. (1998). This selection of functional traits was performed taking into account the traits that represent or allow species success in establishing and developing on the substrates.

Size class was measured under a microscope, and growth form, strength of attachment to the substratum and functional strategies were assessed by species information contained in a specialized bibliography (Sládecková and Sládecek, 1964, 1977; Peterson, 1996; Biggs et al., 1998; Graham and Wilcox, 2000).

\subsection{Data analysis}

The differences in species community attributes (richness, density or biovolume) between hydrological periods were tested by paired $\mathrm{T}$ test, using the hydrological periods as a factor. We analyzed richness, density and biovolume of the functional traits in both hydrological periods and in community dynamics along colonization. To address our first question, we used a factorial two-way analysis of variance to test the differences, using hydrological periods, days of colonization and traits as factors, and their interactions.

A non-metric multidimensional scaling analysis (NMDS) was applied to the matrix of richness, density and biovolume of species traits to summarize the patterns in both hydrological periods. The Bray-Curtis distance was used in these analyses, and the axes of NMDS were tested by a permutational multivariate analysis of variance (PERMANOVA) using hydrological periods as a factor. This analysis was used to address our second question.

A species functional matrix was constructed for both hydrological periods based on four species traits. The functional matrix was standardized and converted into a distance matrix through the mixed-variables coefficient of distance proposed by Pavoine et al. (2009) and subsequently transformed into a dendrogram by the method of average grouping (UPGMA). The cophenetic correlation was observed to assess how the structure of the distance matrix was preserved in the grouping. The functional diversity was achieved from the dendrogram by the index mean 
pairwise distance (MPD) and taking into account the density of traits in this analysis. This measure is considered baseline (i.e., that is sensitive to distant species) because it calculates the distance pair-to-pair between individual species of a community (Webb, 2000). To address our last question, the differences between functional diversity values of hydrological periods were tested by $\mathrm{T}$ test, using hydrological periods as a factor. All analysis was performed in R software (R Development Core Team, 2013).

\section{Results}

\subsection{Density, biovolume and species richness}

The densities ranged from $9.4 \times 10^{3}$ to $93.8 \times 10^{3} \mathrm{ind} \mathrm{cm}^{-2}$ in high waters with the highest values on the 16th day and from $7.9 \times 10^{3}$ to $229.4 \times 10^{3}$ ind $\mathrm{cm}^{-2}$ in low waters with the highest values on the 12 th day. The total mean density between hydrological periods was significantly high in the high water period compared to the low water period $(\mathrm{F}=$ $6.48 ; \mathrm{p}=0.02$ ). The biovolume values ranged from 17.9 $\times 10^{6}$ to $1587.4 \times 10^{6} \mathrm{~mm}^{3} \mathrm{~cm}^{-2}$ in high waters, with the highest values on day 14 , and from $14.7 \times 10^{6}$ to $1244.2 \times$ $10^{6} \mathrm{~mm}^{3} \mathrm{~cm}^{-2}$ in low waters, with the highest values on day 16. The means of total biovolume between hydrological periods were not significantly different $(\mathrm{F}=0.46 ; \mathrm{p}=0.50)$. Species richness varied between 20 and 40 species in high waters, with the highest values on day 8 , and between 23 and 43 species in low waters with the highest values on day 16. The means of richness between hydrological periods were not significantly different $(F=1.20 ; p=0.28)$.

\subsection{Trait dynamics}

Richness was significantly different between hydrological periods $(F=5.13 ; \mathrm{p}=0.02)$ and between traits $(\mathrm{F}=57.69$; $\mathrm{p}=0.001)$. Density was significantly different for all factors (Hydrologic periods: $\mathrm{F}=4.58 ; \mathrm{p}=0.03$; Days of colonization: $\mathrm{F}=11.92 ; \mathrm{p}=0.001$; Traits: $\mathrm{F}=13.54 ; \mathrm{p}=0.001)$ and the interaction between hydrological periods and functional traits $(\mathrm{F}=2.90 ; \mathrm{p}=0.003)$. The biovolume showed significant differences between the days of colonization $(\mathrm{F}=44.74$; $\mathrm{p}=0.04$ ) and the interaction of hydrological period and day of colonization $(\mathrm{F}=6.08 ; \mathrm{p}=0.001)$.

\subsection{Functional strategies}

For species richness, R-strategist species prevailed in both hydrological periods (Figure 1.1A; Figure 1.1B). For the density, in the high water period (Figure 1.2A), there was a predominance of C-S species, and in the low water period (Figure 1.2B), R-strategist species prevailed. Considering species biovolume, in both hydrological periods, C-S strategist species stood out in almost days of colonization (Figure 1.3A; Figure 1.3B).
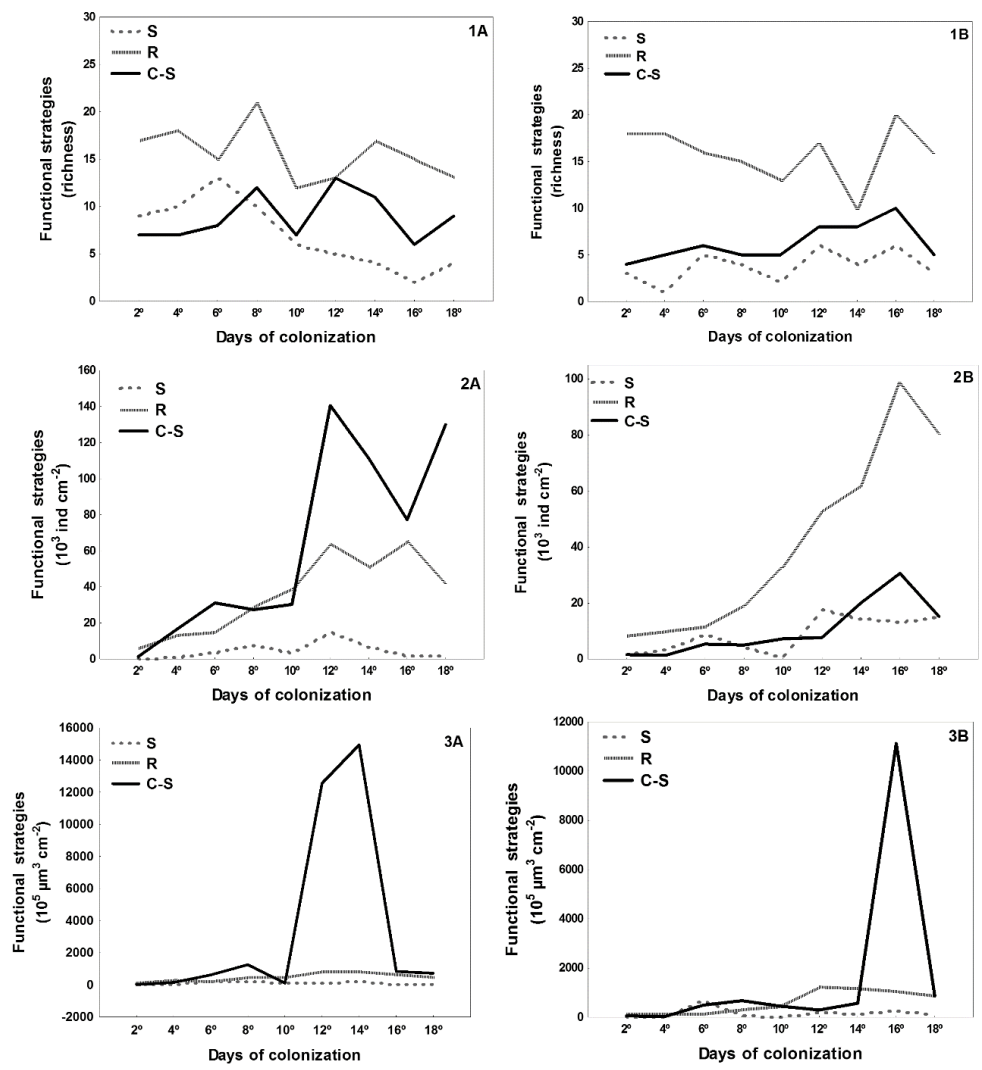

Figure 1. Periphytic algal functional groups during succession in a widely connected lake (Pau Veio)- (1- Richness; 2- Density; 3- Biovolume; (A) High water; (B) Low water). 


\subsection{Attachment to substratum}

Firmly attached species prevailed in richness during the last days of colonization during the high water period (Figure 2.1A). In the low water period (Figure 2.1B), the loosely attached species prevailed during all days of colonization. For the species density, during the high water period, loosely attached species prevailed most days (Figure 2.2A). In the low water period (Figure 2.2B), firmly attached species stood out in density. In relation to the biovolume, during the high water period (Figure 2.3A), firmly attached species prevailed during all successions. In the low water period (Figure 2.3B), loosely attached species excelled during the last four days of colonization.

\subsection{Growth forms}

Unicellular species prevailed in richness during both hydrological periods (Figure 3.1A; Figure 3.1B). Considering density, filamentous species stood out during almost all of the days of colonization during the high water period (Figure 3.2A), and in the low water period (Figure 3.2B), the pattern was reversed, with a predominance of unicellular followed by filamentous species. Regarding species biovolume, filamentous species prevailed throughout colonization during the high water period (Figure 3.3A), and during the low water period (Figure 3.3B), this growth form prevailed up to the $10^{\text {th }}$ colonization day, with a subsequent increase of colonial species.

\subsection{Size classes}

Microperiphytic species prevailed in richness in both high (Figure 4.1A) and low water periods (Figure 4.1B) during colonization. Considering species density, nanoperiphytic species prevailed in the high water period (Figure 4.2A) and microperiphytic species in the low water period (Figure 4.2B). With respect to biovolume, during the high water period (Figure 4.3A), microperiphytic species stood out up to the $10^{\text {th }}$ colonization day, and in the low water period (Figure 4.3B), microperiphytic species prevailed during all days of colonization.

\subsection{Trait structure in both hydrological periods}

The NMDS showed a stress of 0.087 . This ordination was significant for hydrological period (Permanova: $\mathrm{F}=0.86 ; \mathrm{p}=0.05)$. Thus, the differentiation in the trait richness between hydrological periods indicated that unicellular species, the size class microperiphyton and the $\mathrm{R}$-strategists species were more related to the initial days of colonization in low waters, whereas firmly and filamentous species were more related to high waters (Figure 5A).

The NMDS performed with the trait density showed a stress of 0.088 . This ordination was significant for hydrological period (Permanova: $\mathrm{F}=0.68 ; \mathrm{p}=0.04$ ).
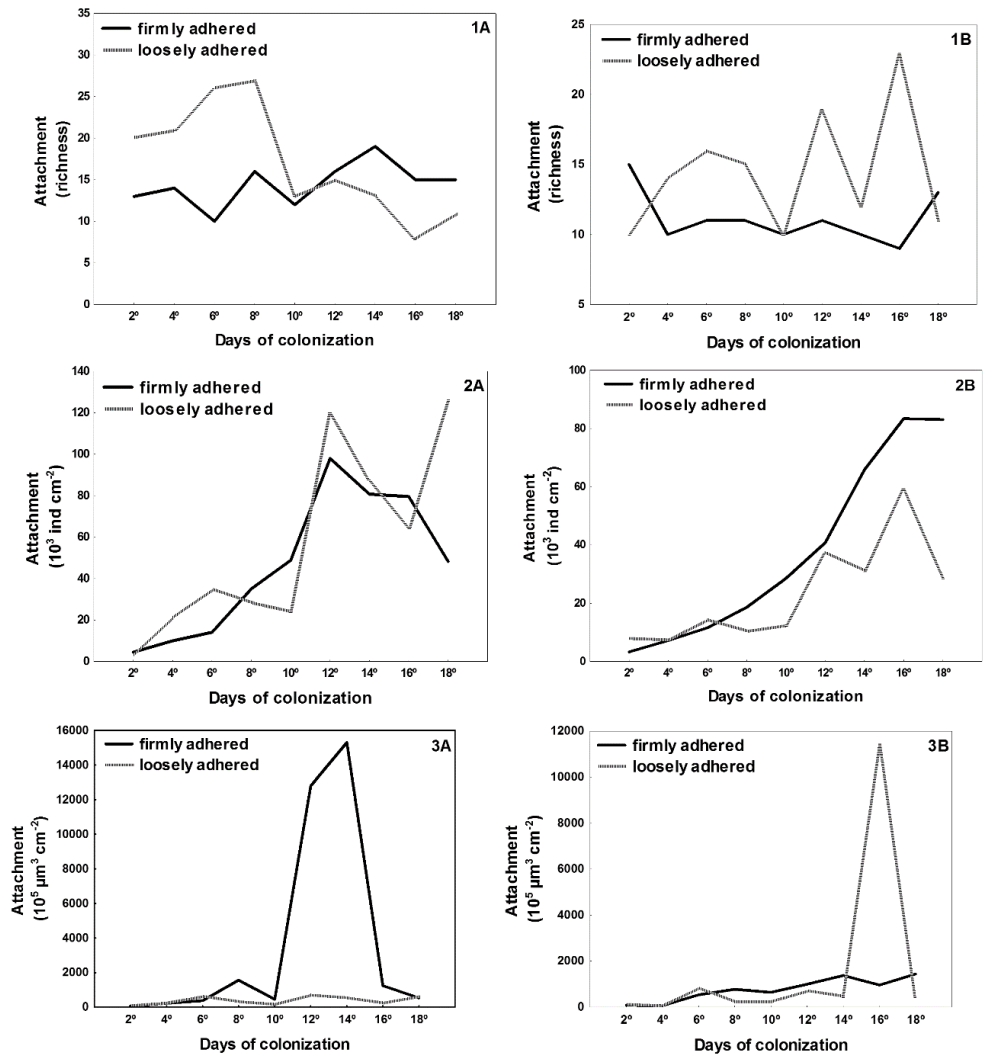

Figure 2. Periphytic algal attachment forms during succession in a widely connected lake (Pau Veio)- (1- Richness; 2-Density; 3- Biovolume; (A) High water; (B) Low water). 

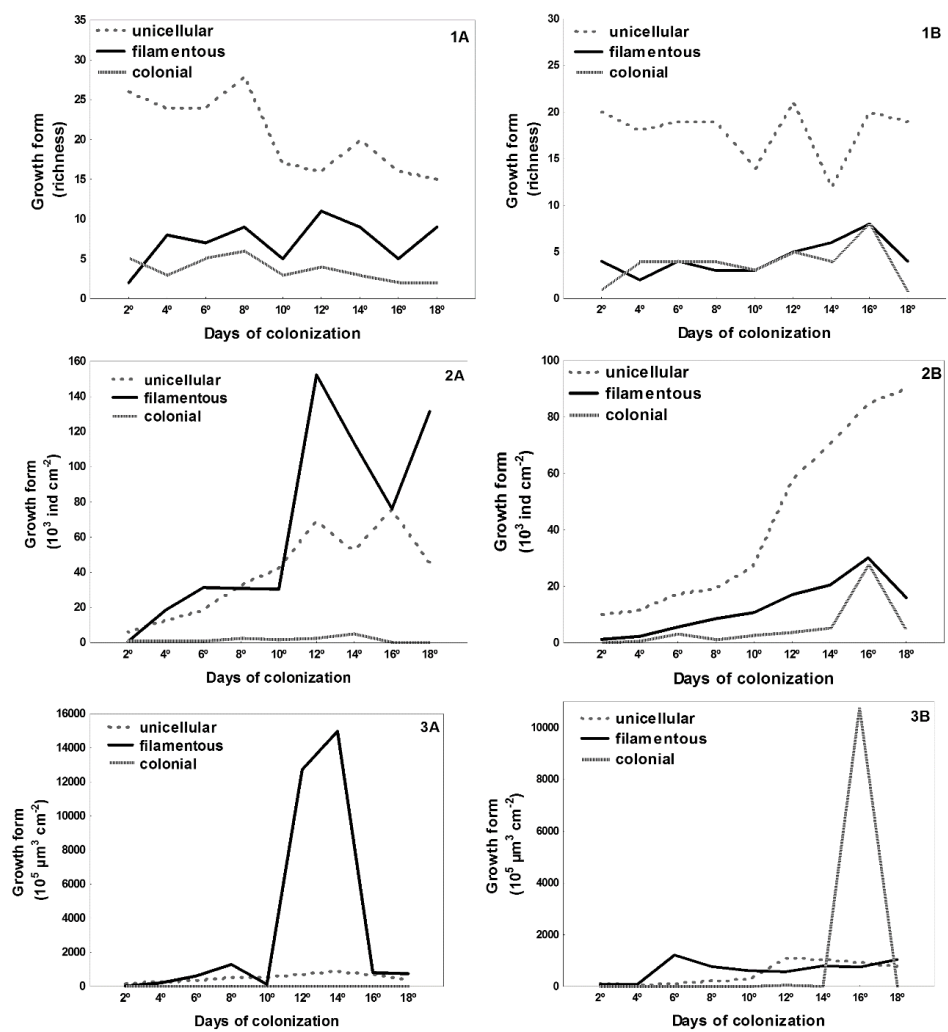

Figure 3. Periphytic algal growth forms during succession in a widely connected lake (Pau Veio)- (1- Richness; 2- Density; 3- Biovolume; (A) High water; (B) Low water).
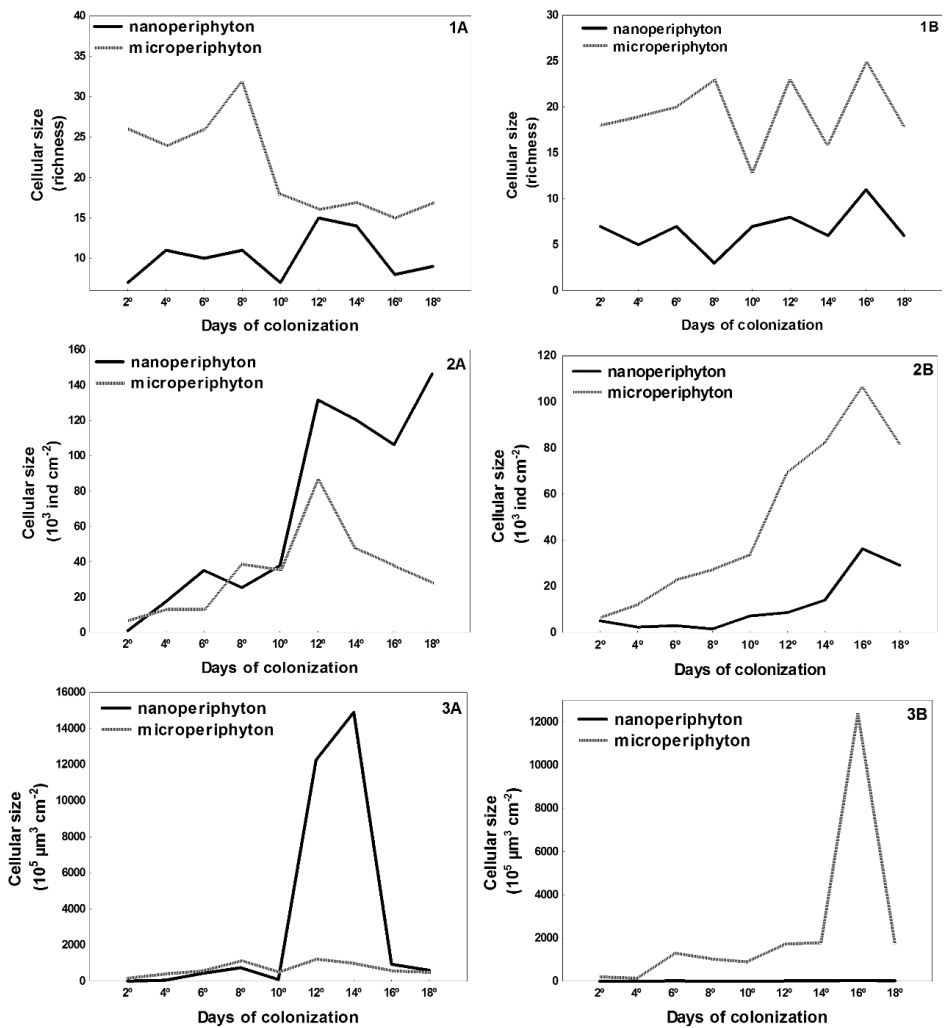

Figure 4. Periphytic algal size classes during succession in a widely connected lake (Pau Veio)- (1- Richness; 2- Density; 3- Biovolume; (A) High water; (B) Low water). 

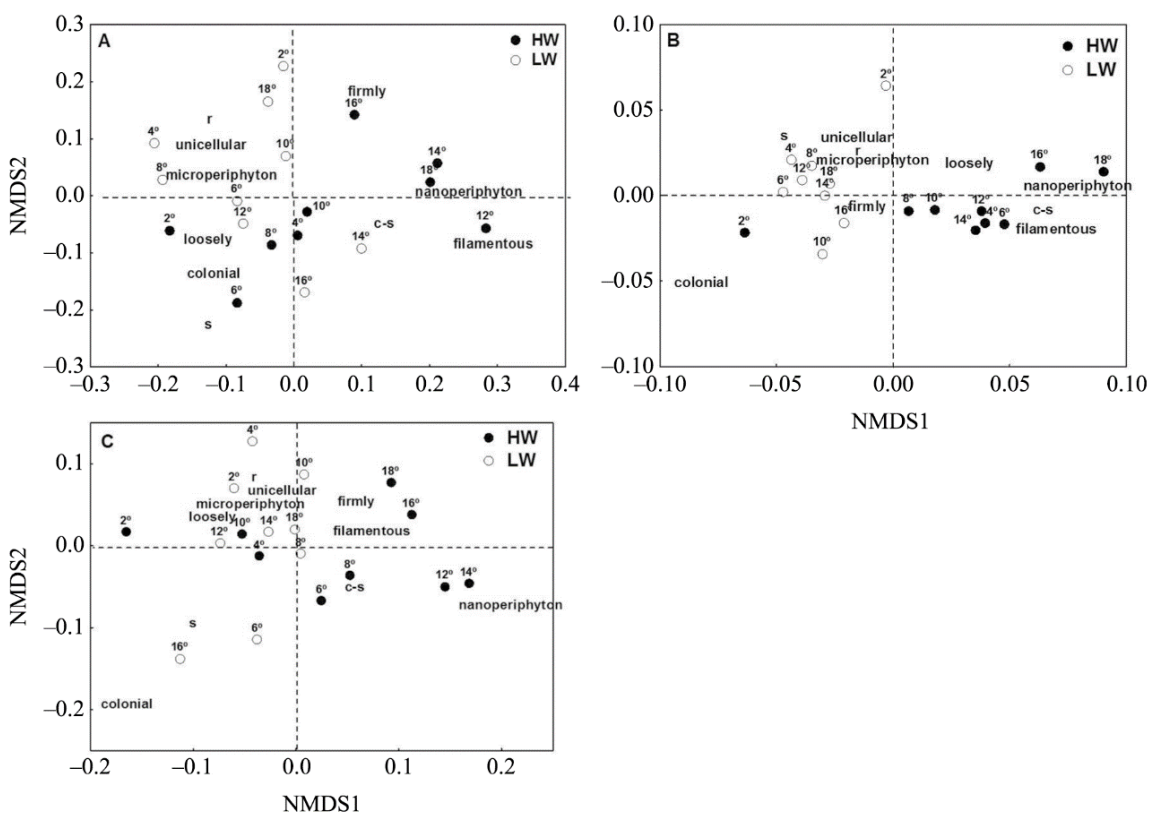

Figure 5. Non-metric multidimensional scaling analysis of richness (A), density (B) and biovolume (C) of species traits patterns in both hydrological periods (HW: High water, LW Low water).

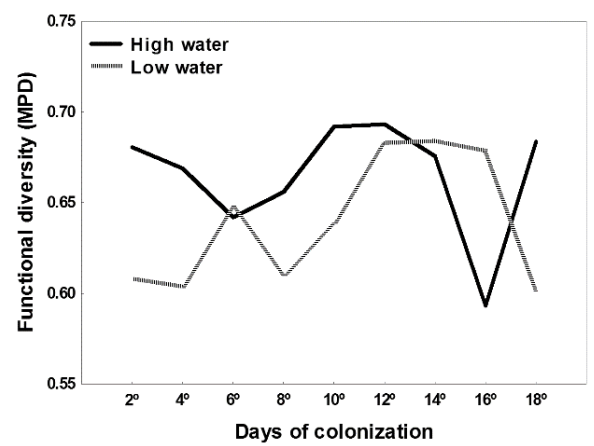

Figure 6. Periphytic algal functional diversity during succession in a widely connected lake (Pau Veio).

Thus, the differentiation in the trait density between hydrological periods indicated that unicellular, firmly, and R-strategists species were more related to low waters, whereas filamentous and C-S strategists species were more related to most days of colonization during high waters (Figure 5B).

The NMDS performed with the traits biovolume showed a stress of 0.120 . This ordination was not significant for hydrological period (Permanova: $\mathrm{F}=-0.94 ; \mathrm{p}=0.93$ ). Thus, although this ordination was not significant, maybe in terms of the number of replicas, the pattern in this ordination showed that firmly and filamentous species were more related to the last days of colonization in high waters, during the peak of biomass (Figure 5C).

\subsection{Functional diversity}

The cophenetic coefficients of functional dendrograms of communities between high and low waters were 0.91 and 0.92 , respectively. This result indicated that much of the distance matrix structure was preserved in the grouping of species. The functional diversity was generally higher during the high water period. This trend was modified on the final days of colonization (Figure 6). During high water, the highest values of functional diversity occurred between the 10th and 12th days of colonization. During low water, the highest values of functional diversity occurred between the 12th and 16th days. The means of functional diversity between hydrological periods were not significantly different $(F=2.59 ; \mathrm{p}=0.12)$.

\section{Discussion}

The flood pulse effect promoted a differentiation in the structure and dynamics of periphytic algae functional traits and functional diversity along a short-term succession process at the Pau Veio Lake. During the colonization and succession processes of periphytic algae, changes occur in the composition of species (taxonomic) and arrangement of organisms in the matrix (physiognomy) (Tuji, 2000), and these patterns can be altered according to environmental changes (Biggs et al., 1998; Carrick and Steinman, 2001). Community structure attributes can respond differently to these changes, and in the present study, the density and richness were the attributes that showed significant differences between hydrological periods.

Studies of phytoplankton or periphyton are usually based on cell volume (or biovolume), a measurement that estimates the contribution of each taxonomic group or taxon to the primary production (Lavoie et al., 2006). The structure of these communities can also be evaluated through the density or relative abundance, but these measurements do 
not represent the differences of cell sizes, and the influence of abundant small cells can be underestimated relative to larger taxa. These two measurements are complementary, and some bioindication studies using periphytic algae have emphasized the use of biovolume as the best method (Reavie et al., 2010). In our study, the density and richness were the most sensitive to the influence of the flood pulse, in addition to being a measure that allows a better identification of succession stages.

Among the functional strategies of periphytic algae, $\mathrm{C}-\mathrm{S}$ species dominated in density in the high water period, when there was a lower availability of nutrients. The homogenizing effect of the flood pulse (Thomaz et al., 1997) promotes dispersal of the species and contributes to the colonization of both $\mathrm{R}$ and $\mathrm{C}-\mathrm{S}$ species during the first ten days of colonization. The instability caused by the pulse may be changed in a few days, and environmental conditions may return to normal, which might have favored the C-S species, which can generally establish and dominate in stable environments with low to moderate intensity of disturbance and under mesotrophic conditions (Carrick and Steinman, 2001). The low environmental instability and the moderate availability of nutrients can be responsible for the predominance of C-S species (Biggs et al., 1998).

Note that there was a greater contribution of C-S species in biovolume in both hydrological periods. This group is composed of unicellular or filamentous organisms, usually with a medium size, which grow vertically or prostate (Carrick and Steinman, 2001) and can contribute in biovolume for the community.

A distinct response was verified for the richness of functional strategies. R-strategist species prevailed in richness in both periods and in density in the low water. The R species group consists of pioneer species, primary colonizers that grow rapidly in highly variable environments by tolerating frequent disturbances with a high variability of resources (Carrick and Steinman, 2001). In physically stable environments, they can also persist by remaining entangled in the matrices along with $\mathrm{C}$ or S-strategist species (Biggs et al., 1998), as in the low water period without an influence of the flood pulse.

A similar result for the dominant functional strategies was reported by Ferragut and Bicudo (2010). In a control condition, similar to our experiment without the flood pulse effect (low water period), R-strategist species dominated the entire succession process. However, under an enrichment condition with phosphorus and nitrogen $(\mathrm{NP}+)$, under the disturbance effect, C-S strategists dominated throughout the succession process in relative density and biovolume. On the other hand, Dunck et al. (2013b) reported that in an isolated floodplain lake, R-strategist species were dominant only in low waters, most likely due to the frequent disturbances with varied availability of resources of this hydrological period.

Regarding the attachment to the substratum, the loosely attached species prevailed in density in both periods. Differences in composition and attachment produce varied three-dimensional physiognomic structures in the periphyton matrix (Tuji, 2000). In succession processes, this matrix consists of layers according to the availability of nutrients, space, light and degree of disturbance (Lowe, 1996), and in general, species on the upper layers without any structure for attachment are more prone to the action of disturbances and may detach more easily. This can explain the predominance of loosely attached species in both periods, from the washout promoted by the flood pulse in the high water period, or by the high connectivity with the river in the low water period.

Along with other adaptive and functional traits, the growth forms of algae are often associated with a species' ability to dominate periphyton communities. The height inside the periphyton matrix is important for providing greater access or increasing the individual probability of acquiring light and resources from above or from the middle (Stevenson, 1996). Filamentous species are favored by the vertical growth that allows greater access to light and nutrients, rapid growth in length and constant area/volume ratio (Margalef, 1983), maintaining high biovolume. These organisms present differentiated structures or cells for attachment to substrates, which favored their permanence in the high water period, under the flood pulse effect. In turn, unicellular species are generally smaller and can have the ability to move, which favors displacement inside the periphyton matrix in the search of available resources. These traits may have favored their greater density in the low water period.

Moreover, the cell size is a strategy that influences the contribution of each species to the total community biomass, and the cell division rate is influenced by this characteristic, as a small cell has a faster growth rate than a large cell (Cox, 1991). Among the size classes evaluated, nanoperiphyton species prevailed in the high water period with lower nutrient availability, and microperiphyton species predominated in the low water period. Studies have reported a reduction in nanoperiphyton species with increased enrichment of environments and a trend to increase the size of organisms in environments with higher nutrient availability (Cattaneo et al., 1997; Ferragut and Bicudo, 2010).

In succession processes, in general, the biomass peaks are related to climax in succession (Biggs et al., 1998). The higher biomass (density and biovolume) in both periods was related to the 12th and 16th days of colonization, similar to that recorded in Brazil by Felisberto and Rodrigues (2012) for a subtropical lotic system in the northwest of Paraná and by Pellegrini and Ferragut (2012) for a mesotrophic tropical reservoir. For the functional diversity, the highest values corresponded to peaks in biomass in both periods. This result is an indication that communities in a biomass peak during a short-term succession process also have greater functional diversity.

Theory predicts that greater differences in species traits (Cadotte et al., 2011) and functional diversity (Diaz and Cabido, 2001) lead to increased ecosystem function (Moretti et al., 2013). Experiments, reviews and meta-analyses have shown that functional diversity is one of the best 
predictors of available ecosystem function (Petchey and Gaston, 2006). In a review, Diaz and Cabido (2001) found that one of the best explanations for the effects of functional diversity on ecosystem function was that higher diversity of functional traits increases resource-use efficiency in heterogeneous environments. Thus, the results indicate that these communities in biomass peak may have greater efficiency in the functioning of ecosystems.

Although the means of functional diversity between hydrological periods were not different in both hydrological periods, the highest values of functional diversity were related to the high water period. This likely occurred due to the expansion of the flooding area and connectivity promoted by the flood pulse in this period. This event provided an increase in temporary habitat available for the species. Because algae possess passive and generally unlimited dispersal (Finlay, 2002), the flood pulse can facilitate this process (Algarte et al., 2014; Dunck et al., 2013b), and thus, species with different functional traits can become established in these environments. These results are similar to those found by Dunck et al. (2013b) when they evaluated functional diversity of periphytic algae from natural substrates in an isolated lake located in the same floodplain. They also concluded that the high water period enhances the variety of niches and that the dispersal is eased by the flood pulse, thereby allowing the development of more species with different functional traits.

In summary, our study demonstrated that the flood pulse promoted alterations in short-term successional processes of periphytic algae. The flood pulse favored a greater development of C-S strategists, loosely attached, filamentous and nanoperiphytic species in succession processes in a semi-lotic ecosystem. The lack of this effect led to the predominance of R-strategists, loosely attached, unicellular and microperiphytic species. We demonstrated that functional traits play an important role in communities and that the highest values of functional diversity were related with the biomass peak during the short-term succession and high water hydrological period. These findings show the importance of the functional traits approach in periphyton studies and that the selection of functional traits must be performed taking into account traits that represent the species niche.

\section{Acknowledgements}

We acknowledge the Coordination for the Improvement of Higher Education Personnel (CAPES), for doctoral scholarship granted for Bárbara Dunck, to the National Council for Scientific and Technological Development (CNPq) for the productivity grant to Liliana Rodrigues, to the Long Term Ecological Research (CNPq-PELD-Brazil), and to the Research center in Limnology, Ichthyology and Aquaculture (Nupélia) for technical and logistical support during the performance of this study. We are also grateful to two anonymous reviewers for valuable comments during previous drafts of this article.

\section{References}

ALGARTE, VM., SIQUEIRA, NS., MURAKAMI, EA. and RODRIGUES, L., 2009. Effects of hydrological regime and connectivity on the interannual variation in taxonomic similarity of periphytic algae. Brazilian Journal of Biology $=$ Revista Brasileira de Biologia, vol. 69, no. 2, supplement, p. 609-616. http://dx.doi. org/10.1590/S1519-69842009000300015. PMid:19738967.

ALGARTE, VM., RODRIGUES, L., LANDEIRO, VL., SIQUEIRA, T. and BINI, LM., 2014. Variance partitioning of deconstructed periphyton communities: does the use of biological traits matter? Hydrobiologia, vol. 772, no. 1, p. 279-290. http:// dx.doi.org/10.1007/s10750-013-1711-6.

BIGGS, BJF., 1996. Patterns in periphyton of streams. In STEVENSON, RJ., BOTHWELL, ML. and LOWE, RL. (Eds.). Algal ecology: freshwater benthic ecosystems. San Diego: Academic Press. p. 31-56.

BIGGS, BJF., STEVENSON, RJ. and LOWE, RL., 1998. A habitat matrix conceptual model for stream periphyton. Archiv für Hydrobiologie, vol. 143, no. 1, p. 21-56.

CADOTTE, MW., CARSCADDEN, K., and MIROTCHNICK, N., 2011. Beyond species: functional diversity and the maintenance of ecological processes and services. Journal of Applied Ecology, vol. 48 , no. 5, p. 1079-1087. http://dx.doi.org/10.1111/j.13652664.2011.02048.x.

CARRICK, HJ. and STEINMAN, AD., 2001. Variation in periphyton biomass and species composition in Lake Okeechobee, Florida (USA): distribution of algal guilds along environmental gradients. Archiv für Hydrobiologie, vol. 152, p. 411-438.

CATTANeO, A., KERIMIAN, T., et al, 1997. Periphyton distribution and abundance on substrata of different size along a gradient of stream trophy de Montréal. Hydrobiologia, vol. 354, no. 1-3, p. 101-110. http://dx.doi.org/10.1023/A:1003027927600.

COX, EJ., 1991. What is the basis for using diatoms as monitors of river quality? In WHITTON, BA., ROTT, E. and FREIDRICH, G. (Eds.). Use of algae for monitoring rivers. Innsbruck: University of Innsbruck. p. 33-40.

DE BELLO, F., LAVOREL, S., LAVERGNE, S., ALBERT, CH., BOULANGEAT, I., MAZEL, F. and THUILLER, W., 2013. Hierarchical effects of environmental filters on the functional structure of plant communities: a case study in the French Alps. Ecography, vol. 36, no. 3, p. 393-402. http://dx.doi.org/10.1111/ j.1600-0587.2012.07438.x.

DÍAZ, S. and CABIDO, M., 2001. Vive la différence: plant functional diversity matters to ecosystem processes. Trends in Ecology \& Evolution, vol. 16, no. 11, p. 646-655. http://dx.doi. org/10.1016/S0169-5347(01)02283-2.

DUNCK, B., NOGUEIRA, IS. and FELISBERTO, SA., $2013 \mathrm{a}$. Distribution of periphytic algae in wetlands (Palm swamps, Cerrado), Brazil. Brazilian Journal of Biology $=$ Revista Brasileira de Biologia, vol. 73, no. 2, p. 331-346. http://dx.doi.org/10.1590/ S1519-69842013000200013. PMid:23917560.

DUNCK, B., BORTOLINI, JC., RODRIGUES, LC., JATI, S., TRAIN, S. and RODRIGUES, L., 2013b. Flood pulse drives functional diversity and adaptative strategies of planktonic and periphytic algae in isolated tropical floodplain lake (Brazil). Brazilian Journal of Botany, vol. 36, no. 4, p. 257-266.

DUNCK, B., SCHNECK, F. and RODRIGUES, L., 2015. Patterns in species and functional dissimilarity: insights from periphytic algae in subtropical floodplain lakes. Hydrobiologia. In Press. http://dx.doi.org/10.1007/s10750-015-2379-x. 
FELISBERTO, SA. and RODRIGUES, L., 2012. Dinâmica sucessional de comunidade de algas perifíticas em um ecossistema lótico subtropical. Rodriguésia, vol. 63, no. 2, p. 463-473. http:// dx.doi.org/10.1590/S2175-78602012000200018.

FERRAGUT, C. and BICUDO, DC., 2009. Efeito de diferentes níveis de enriquecimento por fósforo sobre a estrutura da comunidade perifítica em represa oligotrófica tropical (São Paulo, Brasil). Revista Brasileira de Botanica. Brazilian Journal of Botany, vol. 32, no. 3, p. 571-585. http://dx.doi.org/10.1590/ S0100-84042009000300015.

FERRAGUT, C. and BICUDO, DC., 2010. Periphytic algal community adaptive strategies in $\mathrm{N}$ and $\mathrm{P}$ enriched experiments in a tropical oligotrophic reservoir. Hydrobiologia, vol. 646, no. 1, p. 295-309. http://dx.doi.org/10.1007/s10750-010-0168-0.

FINLAY, BJ., 2002. Global dispersal of free-living microbial eukaryote species. Science, vol. 296, no. 5570, p. 1061-1063. http://dx.doi.org/10.1126/science.1070710. PMid:12004115.

GOLDSBOROUGH, LG. and ROBINSON, GGC., 1996. Pattern in wetlands. In STEVENSON, RJ., BOTHWELL, ML. and LOWE, RL. (Eds.). Algal ecology in freshwater benthic ecosystems. San Diego: Academic Press. p. 77-117.

GRAHAM, LE. and WILCOX, LW., 2000. Algae. New Jersey: Prentice Hall. 640 p.

HILLEBRAND, H., DÜRSELEN, C., KIRSCHTEL, D., POLLINGHER, U. and ZOHARY, T., 1999. Biovolume calculation for pelagic and benthic microalgae. Journal of Phycology, vol. 35, no. 2, p. 403-424. http://dx.doi.org/10.1046/j.1529-8817.1999.3520403.x.

JUNK, WJ. and WANTZEN, KM., 2004. The flood pulse concept: new aspects, approaches, and applications- an update. In WELCOMME, R. and PETR, T. (Eds.). Proceedings of the 2nd Large River Symposium (LARS), 2004. Pnom Penh, Cambodia. Bangkok. FAO Regional Office for Asia and the Pacific. p. 117-149.

JUNK, WJ., BAYLEY, PB. and SPARKS, SI., 1989. The flood pulse concept in river-floodplain systems. Canadian Journal of Fishers and Aquatic, vol. 106, p. 110-127.

LARSON, CA. and PASSY, SI., 2012. Taxonomic and functional composition of the algal benthos exhibits similar successional trends in response to nutrient supply and current velocity. FEMS Microbiology Ecology, vol. 80, no. 2, p. 352-362. http://dx.doi. org/10.1111/j.1574-6941.2012.01302.x. PMid:22239720.

LAVOIE, I., CAMPEAU, S., FALLU, M-A. and DILLON, PJ., 2006. Diatoms and biomonitoring: should cell size be accounted for? Hydrobiologia, vol. 573, no. 1, p. 1-16. http://dx.doi. org/10.1007/s10750-006-0223-Z

LAVOREL, S., STORKEY, J., LAVOREL, S., STORKEY, J., BARDGETT, RD., DE BELLO, F., BERG, MP., LE ROUX, X., MORETTI, M., MULDER, C., PAKEMAN, RJ., DÍAZ, S. and HARRINGTON, R., 2013. A novel framework for linking functional diversity of plants with other trophic levels for the quantification of ecosystem services. Journal of Vegetation Science, vol. 24 , no. 5, p. 942-948. http://dx.doi.org/10.1111/jvs.12083.

LOWE, RL., 1996. Periphyton patterns in lakes. In STEVENSON, RJ., BOTHWELL, ML. and LOWE, RL. (Eds.). Algal ecology in freshwater benthic ecosystems. San Diego: Academic Press. p. 3-30.

MARGALEF, R., 1983. Limnologia. Barcelona: Ediciones Omega. $1009 \mathrm{p}$

MCCORMICK, PV., 1996. Resource competition and species coexistence in freshwater benthic algal assemblages. In
STEVENSON, RJ., BOTHWELL, ML. and LOWE, RL. (Eds.). Algal ecology in freshwater benthic ecosystems. San Diego: Academic Press. p. 229-252.

MORETTI, M., DE BELLO, F., IBANEZ, S., FONTANA, S., PEZZATTI, GB., DZIOCK, F., RIXEN, C. and LAVOREL, S., 2013. Linking traits between plants and invertebrate herbivores to track functional effects of land-use changes. Journal of Vegetation Science, vol. 24, no. 5, p. 949-962. http://dx.doi. org/10.1111/jvs.12022.

MURAKAMI, EA. and RODRIGUES, L., 2009. Resposta das algas perifíticas às alterações de temperatura $\mathrm{e}$ ao enriquecimento artificial de nutrientes em curto período de tempo. Acta Scientiarum Biological Sciences, vol. 31, no. 3, p. 273-284. http://dx.doi. org/10.4025/actascibiolsci.v31i3.1627.

PAVOINE, S., VALLET, J., DUFOUR, A-B., GACHET, S. and DANIEL, H., 2009. On the challenge of treating various types of variables: application for improving the measurement of functional diversity. Oikos, vol. 118, no. 3, p. 391-402. http:// dx.doi.org/10.1111/j.1600-0706.2008.16668.x.

PELLEGRINI, BG. and FERRAGUT, C., 2012. Variação sazonal e sucessional da comunidade de algas perifíticas em substrato natural em um reservatório mesotrófico tropical. Acta Botanica Brasílica, vol. 26, no. 4, p. 810-821. http://dx.doi.org/10.1590/ S0102-33062012000400010.

PETCHEY, OL. and GASTON, KJ., 2006. Functional diversity: back to basics and looking forward. Ecology Letters, vol. 9, no. 6, p. 741-758. http://dx.doi.org/10.1111/j.1461-0248.2006.00924.x. PMid:16706917.

PETERSON, CG., 1996. Response of benthic algal communities to natural physical disturbance. In STEVENSON, RJ., BOTHWELL, ML. and LOWE, RL. (Eds.). Algal ecology in freshwater benthic ecosystems. San Diego: Academic Press. p. 375-402.

R Development Core Team, 2013. R: A language and environment for statistical computing. The R Foundation. Available from: $<$ http://www.R-project.org>. Access in: 05 Feb. 2013.

REAVIE, ED., JICHA, TM., ANGRADI, TR., BOLGRIEN, DW. and HILL, BH., 2010. Algal assemblages for large river monitoring: Comparison among biovolume, absolute and relative abundance metrics. Ecological Indicators, vol. 10, no. 2, p. 167-177. http:// dx.doi.org/10.1016/j.ecolind.2009.04.009.

REYNOLDS, CS., 1997. Vegetation processes in the pelagic: a model for ecosystem theory. Germany: Ecology Institute. $371 \mathrm{p}$. Excellence in Ecology, no. 9

RODRIGUES, L. and BICUDO, DC., 2001a. Similarity among periphyton algal communities in a lentic-lotic gradient of the upper Paraná river floodplain, Brazil. Brazilian Journal of Botany, vol. 24, no. 3, p. 235-248. http://dx.doi.org/10.1590/ S0100-84042001000300001

RODRIGUES, L. and BICUDO, DC., 2001b. Limnological characteristics comparison in three systems with different hydrodynamic regime in the upper Paraná river floodplain. Acta Limnologica Brasiliensia, vol. 13, no. 1, p. 39-49.

RODRIGUES, L. and BICUDO, DC., 2004. Periphytic Algae. In THOMAZ, SM., HAHN, NS. and AGOSTINHO, AA. (Eds.). The Upper Paraná River and its floodplain: physical aspects, ecology and conservation. Leiden: Backhuys Publishers. p. 125-143.

ROS, J., 1979. Práctica de ecologia. Barcelona: Omega. 181 p.

SCHNECK, F. and MELO, AS., 2012. Hydrological disturbance overrides the effect of substratum roughness on the resistance 
and resilience of stream benthic algae. Freshwater Biology, vol. 57, no. 8, p. 1678-1688. http://dx.doi.org/10.1111/j.13652427.2012.02830.x.

SLÁDECKOVÁ, A. and SLÁDECEK, V., 1964. Periphyton as indicator of the reservoir water quality. I - True-periphyton. Technology of water, vol. 7, p. 507-561.

SLÁDECKOVÁ, A. and SLÁDECEK, V., 1977. Periphyton as indicator of the reservoir water quality. II - Pseudo-periphyton. Archiv für Hydrobiologie, vol. 9, p. 176-191.

SMITH, B. and WILSON, JB., 2002. Community convergence: ecological and evolutionary. Folia Geobotanica, vol. 37, no. 2, p. 171-183. http://dx.doi.org/10.1007/BF02804230.

SOBRAL, FL. and CIANCIARUSO, MV., 2012. Estrutura filogenética e funcional de assembléias: (re)montando a ecologia de comunidades em diferentes escalas espaciais. Bioscience Journal, vol. 28, no. 4, p. 617-631.

STEVENSON, RJ., 1990. Benthic community dynamics in a stream during and after a spate. Journal of the North American Benthological Society, vol. 9, no. 3, p. 277-288. http://dx.doi. org/10.2307/1467591.

STEVENSON, RJ., 1996. An introduction to algae ecology in freshwater benthic habitats. In STEVENSON, RJ., BOTHWELL, ML. and LOWE, RL. (Eds.). Algal ecology in freshwater benthic ecosystems. San Diego: Academic Press. p. 3-30.
THOMAZ, SM., BINI, LM. and ALBERT, SM., 1997. Limnologia do reservatório de Segredo: padrões de variação espacial e temporal. In AGOSTINHO, AA. and GOMES, LC. (Eds.). Reservatório de segredo: bases ecológicas para o manejo. Maringá: Eduem. p. 19-37.

TILMAN, D., 2001. Functional diversity. In LEVIN, SA. (Ed.). Encyclopedia of biodiversity. San Diego: Academic Press. p. 109-120.

TUJI, A., 2000. Observation of developmental processes in loosely attached diatom (Bacillariophyceae) communities. Phycological Research, vol. 48, no. 2, p. 75-84. http://dx.doi. org/10.1111/j.1440-1835.2000.tb00199.x.

UTERMÖHL, H., 1958. Zur Vervollkommnung der quantitativen phytoplankton-methodic. Stuttgart: Schweizerbart. 38 p. Mitteilungen / Internationale Vereinigung fuer Theoretische und Angewandte Limnologie, no. 9.

WEBB, CO., 2000. Exploring the phylogenetic structure of ecological communities: an example for rain forest trees. American Naturalist, vol. 156, no. 2, p. 145-155. http://dx.doi. org/10.1086/303378. PMid:10856198.

WEITHOFF, G., 2003. The concepts of 'plant functional types' and 'functional diversity' in lake phytoplankton - a new understanding of phytoplankton ecology? Freshwater Biology, vol. 48, no. 9, p. 1669-1675. http://dx.doi.org/10.1046/j.1365-2427.2003.01116.x. 